\title{
Research on Extension and Application of Teaching Reform Achievements in Universities
}

\author{
Bing Liu ${ }^{1, \text { a }}$, Jianping Sun ${ }^{2, *}$ \\ ${ }^{1}$ Academy of Fine Arts, Northeast Normal University, Changchun130024, China; \\ ${ }^{2}$ School of Resources, Environment and Materials, Guangxi University, Nanning530000, China \\ a ice8515@163.com \\ * Corresponding author
}

Keywords: Institutions of higher learning; Reform in education; reform measures; Application and extension of achievements.

\begin{abstract}
Teaching reform is the source of social civilization and progress, and the foundation for sustainable development of colleges and universities. This paper studies the measures of teaching reform in Colleges and universities, and puts forward specific strategies to effectively improve the application and promotion of teaching reform results. Research shows: colleges and universities regularly hold seminars on teaching and research topics and results-based learning, adopt multimedia teaching, increase the breadth and depth of teaching content; build network courses, establish a research group system, and attach importance to the writing of research papers, can effectively promote the teaching quality and scientific research level of teaching teams. As the core of school education reform, the application and popularization of teaching results have become the key to the transformation of colleges and universities, and have a direct impact on the effectiveness of curriculum reform.
\end{abstract}

\section{Introduction}

The teaching work in Colleges and universities is the key factor to realize the goal of talent cultivation, and improve the quality of talent cultivation; the research focus of higher education is the reform of education and teaching [1]. The research on the reform of higher education and teaching includes not only the content of the reform, but also the process of its implementation.

With the deepening of China's teaching reform, colleges and universities take the national education policy as the standard; strictly follow the inherent law of education and teaching. Major colleges and universities combine professional characteristics, give full play to the advantages of the school's disciplines, improve teaching methods and means (heuristic, interactive and practical), and the use of a variety of experimental teaching methods of cross-integration, enhanced students' interest and learning effect [2-3]. We should emphasize the role of scientific research in promoting teaching, and transform scientific research achievements into classroom experimental teaching, so as to promote the mutual promotion and development of experimental teaching and scientific research [4]. In practice teaching, the achievements of teaching and research will be popularized and applied, effectively improving the teaching and scientific research level of the teaching team, and promoting the teaching quality [5].

\section{Analysis of Measures in Teaching Reform in Colleges and Universities}

\subsection{With the cultivation of basic scientific research skills and innovative ability as the core.}

Efforts should be made to carry out teaching work, in line with the principle of people-oriented, in all aspects of theoretical and practical teaching, to strengthen students' ideological education and professional knowledge education.

\subsection{Deepening quality course construction.}

Further deepen the construction of quality courses, with the construction of quality courses as the source, drive the construction of related courses. 


\subsection{Strengthening professional English teaching and bilingual teaching.}

Professional English teaching should pay attention to the training of students' ability to read English literature, interpret and communicate on the spot, and write scientific papers. At the same time, we will further develop bilingual teaching, and actively introduce advanced foreign teaching materials and relevant teaching literature.

\subsection{Actively popularize multimedia and network teaching.}

Strive for the backbone professional courses and provincial and school-level quality courses, $100 \%$ to achieve multimedia teaching, and take the lead in network teaching.

\subsection{Cultivation of students' autonomous learning ability.}

In the course of teaching, we should guide students' self-learning ability, strengthen students' innovative spirit and practical ability, perfect the practical teaching system, cultivate students' scientific research accomplishment and innovative ability in practice.

\subsection{Improve teaching quality with scientific research advantages.}

To improve the teaching quality with the advantage of scientific research, broaden and strengthen the connotation and extension of students' basic theory and professional knowledge. Paying close attention to the development of science and technology in this major, taking curriculum teaching as the core, interdisciplinary integration and interdisciplinary development. Guided by basic research, we are committed to the direction of characteristic research, advocating academic freedom and paying attention to original innovation.

\section{Application and Popularization of Teaching Reform Achievements}

\subsection{Held of teaching seminar.}

The teaching team regularly holds teaching reform research projects or results learning seminars every semester. In the seminar, teachers are encouraged to introduce their own teaching experience and achievements, and exchange teaching experience around teaching reform or scientific research achievements. Promote the communication and mutual learning among teachers in the teaching team, make the teaching reform and scientific research achievements get the greatest promotion and application, but also promote the rapid growth of young teachers.

\subsection{Popularization of multimedia teaching.}

In multimedia teaching, the use the form of picture and text, so that rational knowledge and perceptual knowledge combined, to promote students to understand and absorb the knowledge learned, thus forming a deep impression in the mind. Multimedia teaching method is adopted to enrich the atmosphere of teaching and learning, enhance students' interest in learning basic theoretical knowledge, and expand students' knowledge vision. Encourage the teaching team to adopt the multi-media way to teach, and make the multi-media courseware with the same advanced level of domestic universities; In the courseware, there are not only abundant pictures, but also vivid animations, which make the teaching more vivid, and integrate professional English vocabulary into the courseware, improve students' professional English ability, and expand students' knowledge reserves.

\subsection{Construction of network courses.}

To carry out the construction of Web-based courses, perfect the open courses, popularize the syllabus and videos of the courses step by step, and set up discussion areas for the exchange of teachers and students. Teachers can make full use of the abundant information on the websites for learning guidance and exchange, thus realizing the timely interactive teaching on the web.

\subsection{Integration of multiple teaching methods}

Combining the characteristics and actual situation of modern college students, combining various teaching methods, integrating quality education into scientific research and teaching, promoting students' interest in the curriculum, and improving students' theory and practice.

A: Case-based teaching method: 
In teaching, a large number of entity models and pictures are designed and produced, and the application of products is analyzed with actual production examples, so that students can deepen their understanding of knowledge, and promote the absorption of knowledge by referring to entity models.

B: Practical teaching methods:

We should build professional practice bases, encourage students to go to relevant enterprises and markets for research and investigation, and further promote the understanding and absorption of knowledge in practice.

C: Innovative teaching methods:

The latest achievements and information in scientific research and practical teaching are introduced into multimedia teaching, and enrich teaching methods, broaden students' knowledge horizon, and cultivate students' self-learning ability and scientific research enterprising spirit.

D: Skill training teaching method:

Pay attention to the cultivation of students' practical ability, encourage students to participate in scientific research, combine theory with practice, promote students' understanding of knowledge and improve the quality of teaching in practice.

\subsection{Establishment of scientific research group system}

In practice teaching, the scientific research group system should be established, encourage students to conduct scientific research. In scientific research, we should promote students' practical ability, make students fully apply the study of professional theoretical knowledge to specific scientific research; train students' ability to think independently and solve problems, promote students' interest in professional learning, tap students' professional potential, and then improve students' innovative ability.

\subsection{Writing and publishing scientific research papers}

In teaching reform and research, in order to promote the exchange between teachers, the contents of teaching research results are summarized into academic papers, and exchanged in internal teaching research, or published in various journals, so as to widen the scope of teaching research results and enhance their research value.

\section{Conclusion}

The application and popularization of the measures and achievements of teaching reform in Colleges and universities, is the necessary requirement and important guarantee for improving teaching quality.

In the teaching reform, it has become the most important task to take teaching research as the forerunner, to take teaching reform as the core, to improve the quality and level of teaching, to actively carry out teaching reform and research, and to popularize the teaching research results to practical teaching as soon as possible.

Strengthen the close combination of teaching and teaching results, make full use of modern teaching methods, build students' autonomy of self-study and participation in scientific research, can effectively enhance and consolidate the application and promotion of teaching results, and realize the demand of modern society for scientific and technological talents. It is expected that the above research can provide some reform ideas for the promotion of curriculum reform in Chinese universities.

\section{Acknowledgment}

The author gratefully thanks the financial support by Fundamental Research Funds for the Central Universities/Youth fund of Northeast Normal University in philosophy and social science projects(2017QT008).

\section{References}

[1]. Rui Zhang, Dajun, Xu. "Research and Application of the Teaching Mode of Information Technology and Ideological and Political Education in Universities,” Agro Food Industry Hi- tech, vol. 28, 2017, pp. 606-610. 
[2]. Yu, Kanhua. "Application of the Web Quest teaching mode in courses of civil engineering specialty,” World Transactions on Engineering and Technology Education, vol. 13, 2015, pp. 174-178.

[3]. Wang Ling. "Research on the integration of Ideological and political theory course and information technology in the University,” Science and Technology Information, vol.43, 2013, pp. 278-280.

[4]. Qiaoyi Wang, Juan Chen. "Teaching reform and thinking of the course electro-mechanical systems dynamics based on higher engineering education mode,” Applied Mechanics and Materials, vol. 397-400, 2013, pp. 2739-2742.

[5]. Junfei Wang, Xiaodong Li, Ming Fu. "Standardized Management of College Teaching Reform Project and Teaching Achievement Popularization and Application," Value Engineering, vol.4, 2016, pp.195-197. 